\title{
ИЗУЧЕНИЕ СЛОЖНЫХ ВОПРОСОВ ИСТОРИИ ЧЕРЕЗ КРАЕВЕДЕНИЕ
}

\author{
Петрова Владлена Вячеславовна \\ преподаватель \\ МОУ «СОШ им. А.П. Чехова»
}

\begin{abstract}
Аннотация: Патриотическое воспитание сегодня - одно из приоритетных направлений нашего государства. И, в первую очередь, задача воспитания истинного патриота стоит перед школой. Но патриотизму нельзя научить, его возможно воспитать, исподволь, на уроках, во внеурочной деятельности. Уроки истории - именно тот материал, где эта задача решается наиболее успешно. И, конечно же, этому способствует краеведение. Краеведение, на наш взгляд, это основа патриотического воспитания. Ведь еще академик Д. С. Лихачев говорил, что из любви к малой родине рождается любовь к Отчизне. Краеведение дает широкие возможности для исследовательской, проектной деятельности учащихся. Недаром это направление включено в Программу воспитания школы. Кроме того, через краеведение можно объяснять сложные вопросы истории. Так, Земскую реформу Александра II мы на уроках истории в 9 классе изучаем через историю Чикинской земской больницы, где начинал свою деятельность врача А. П. Чехов. Материалы, используемые в статье, собраны учениками в ходе проектно - исследовательской деятельности. Они могут использоваться на уроках истории, литературы, МХК, внеклассной работе.
\end{abstract}

Ключевые слова: Патриотизм, краеведение, земская медицина, А. П. Чехов.

Российская земская медицина, основные направления ее разнообразной и исключительно полезной деятельности принадлежат к тем областям государственной и общественной жизни России, которые еще недостаточно изучены, но которые составляют культурное общенациональное богатство российского народа. Недаром из земских врачей вышли не только знаменитые медики, такие как выдающийся хирург В.Ф. Войно - Ясенецкий, известный впоследствии как епископ Лука, но и великие русские писатели М.А. Булгаков, В. В. Вересаев, А. П. Чехов. 
Различные аспекты проблемы становления и развития земской медицины освещены в работах многих российских историков: Лаптевой Л. Е., Шутова А.Ю., Сорокиной Т. С., Заблудовского П.Е., Жуковой Л. Н., Канцельбогена А.Г., Белицкой Е.Я., Левит М.М и др. Большой вклад в изучение данной проблемы внесли труды земских медиков. Таких, как: Веселовский Б.Б., Куковякин С.А., Капустин М.Я., Осипов Е.А., Попов И.В., Куркин П.И., Новиков А.И., Архангельский П. А., Мицкевич С. И.

Однако, несмотря на интерес к проблеме, многие ее аспекты являются недостаточно изученными. Большая часть трудов по данной теме написана на рубеже XX столетия. Кроме того, изучение развития земской медицины помогает лучшему пониманию истории родного края, жизни и быта российской глубинки до и после земской реформы 1864 г. Этим объясняется актуальность выбранной темы работы.

В уездах Российской империи до земской реформы 1864г. врачебная помощь существовала исключительно в уездных городах. Сельских больниц не было вообще. В губерниях были созданы специальные врачебные округа, по одному или несколько на губернию. Округ возглавлялся врачом, в каждой волости имелся фельдшер и два оспопрививателя. Медицинская часть, предназначенная для обслуживания казенных и удельных крестьян, содержалась за счет средств так называемого сословного сбора, собираемого с самих крестьян. Однако, несмотря на достаточно развитый бюрократический аппарат, из - за катастрофически малого количества врачей и младшего медицинского персонала (фельдшера, повивальные бабки и оспопрививатели) и сравнительно высокой для крестьян платы за лечение сельское население пользовалось в основном услугами знахарей и костоправов. Особенно наглядно несостоятельность государственных структур в области медицинского обслуживания населения проявлялась в период эпидемических вспышек.

До введения земств в Российской империи, по данным Медицинского департамента МВД (1856), в 54 губерниях насчитывалось 494 больницы в губерниях и уездах, находящиеся в ведении приказов общественного призрения. Пропускная способность больниц, ввиду малочисленности коек, была невелика (в 1856 г. через все больницы Российской империи, по официальным данным, прошли 312423 человека, из которых умерли 31995 , т.е. каждый десятый больной). Лечение в больницах общественного призрения было платным. [1] 
Земская медицина появилась вместе с земствами. Согласно “Положению о земских учреждениях" 1864 года на земства было возложено "попечение в пределах, законом определенных и преимущественно в хозяйственном отношении, о народном здравии”. [2] Однако, “попечение о народном здравии" было отнесено к числу необязательных повинностей земства. Закон обязывал земства только содержать переданные им учреждения бывших Приказов общественного призрения (губернские больницы, психиатрические лечебницы) и принимать меры в организации оспопрививания. Тем не менее, земские деятели исходили из того, что медицинская помощь, организуемая на земские средства, должна быть равномерно развитой во всех частях уезда и быть бесплатной для всех плательщиков земских повинностей.

\section{Воскресенская земская больница}

Создание земской медицинской сети в Московской губернии началось вскоре после реформы. Уже в 1866 г. была выработана концепция врачебномедицинской помощи населению. Было решено создать на каждые 20 тысяч человек медицинский пункт с врачом, фельдшером и акушеркой. При этом максимальное расстояние от самой дальней деревни до этого пункта не должно было превышать 15 - 17 верст. Первыми губернскими земскими больницами были Воскресенская и Солнечногорская. Воскресенском до 1930х годов назывался наш город Истра.

Создание Воскресенской земской лечебницы было примером того, как руководители губернской управы использовали все, казалось бы, случайные возможности для осуществления своей программы. В 1877 году земство, устраивая госпитали для раненых в русско-турецкой войне, купило участок с полуразрушенными зданиями бывшей фабрики купца П.Д. Чикина в двух верстах от Воскресенска. На участке был лес и хороший пруд. Часть денег выделила губернская земская управа, средства для оборудования госпиталя собрали добровольцы.[8] Патриотический подъем во время войны за освобождение Болгарии был необычайно высок и сбор средств шел успешно. Устройством госпиталя занимался известный земский деятель П.Д. Голохвастов. Был устроен сбор денег, 3 тысячи рублей поступили от фабриканта П.Г. Цурикова, многие присылали мебель, одеяла, другие необходимые вещи. В короткое время был оборудован госпиталь на 20 коек, аптека, прачечная, квартиры для служащих. В следующем году, когда госпиталь перестал функционировать, губернская управа решила вос- 
пользоваться уже созданным врачебным заведением и открыть новый медицинский участок. Уездная больница была далеко, а врачи при фабрике П.Г.Цурикова не могли взять на себя ответственность за столь большую территорию. Активное участие в созании новой больницы принял местный помещик, владелец усадьбы Зенькино Николай Владимирович Рукин (18501894), который в $1875-81$ и в 1884-85 гг. был звенигородским уездным предводителем дворянства.(9)

В 1879 году лечебница была открыта. Она полностью содержалась губернским земством. Город Воскресенск платил тысячу рублей в год, за что имел «2 кровати в Воскресенской лечебнице, амбулаторный прием и вообще все, что может понадобиться в смысле обеспечения жителей врачебной помощью». Воскресенский Ново - Иерусалимский монастырь за одну койку и медицинскую помощь платил 350 рублей. (4) В дальнейшем отношения больницы с промышленными предприятиями расширялись. Московское губернское земство обязало всех владельцев фабрик на свой счет организовать медицинскую помощь рабочим. При крупных фабриках начали создавать собственные лечебницы, остальные заключали с больницами договоры об обслуживании. Больница, рассчитанная на 30 кроватей, с одним врачом, двумя акушерками и двумя фельдшерами от земства, на начало XX в. имела соглашения с Алексинской фабрикой Петрова, торфоразработками на Баевом болоте, с Московско - Виндавской железной дорогой. Лишь владелец шелкомотальной фабрики Нерсесов упорно отказывался оплачивать ее услуги. [8]

С 1878 г. в Воскресенской лечебнице работал врач П.А. Архангельский. Павел Арсеньевич Архангельский (1852-1913 или 1914) окончил медицинский факультет Московского университета в октябре 1876 года и сразу же стал земским врачом в Верейском уезде. В Воскресенске он проработал 17 лет и можно утверждать, что именно он создал известную всей медицинской России лечебницу. С конца 1870-х годов в Московской губернии регулярно проводились съезды земских врачей, активным участником которых был Архангельский. Практически каждый съезд отмечал чрезвычайно успешную постановку дела в больнице, которой он руководил. В 1880-х гг. Архангельский по заданию губернского земства провел обследование психиатрических больниц Московской губернии, которое вылилось в большую научную работу, позднее опубликованную. В книгу вошло описание тринадцати психиатрических заведений, с анализом их работы, с планами зданий. 
К концу 1880-х гг. П.А. Архангельский занял ведущее положение среди врачей губернии. Именно ему была поручена корректировка основных положений деятельности земских лечебных заведений. Продолжает он и конкретную работу, выходящую за пределы его больницы. В начале 1890-х гг. была построена лечебница в селе Пятница-Берендеево. Устройство нового врачебного участка шло под руководством П. А. Архангельского. Это во многом облегчило жизнь Воскресенской больнице и приблизило врачебную помощь к самым глухим селам губернии. [4]

Как и многие земские врачи, П. А. Архангельский много занимался статистикой. Он провел подробнейшее описание санитарного состояния всех школ Звенигородского уезда. (Воскресенск входил в тот момент в Звенигородский уезд). В этой скрупулезной работе приведено огромное количество сведений о школах, их истории, зданиях, преподавателях, расписаниях занятий и отдыхе школьников.

По инициативе П.А. Архангельского в 1896 году было создано Благотворительное общество при Воскресенской больнице, которое собирало деньги для содержания яслей при лечебнице. Членом Благотворительно общества был и А.П. Чехов. После его смерти именно это общество организовало библиотеку - читальню имени Чехова в городе Воскресенске. [8]

После отставки П.А. Архангельского, с 1896 г. и до самой своей кончины в 1908 году главным врачом больницы был талантливый врач, ученый, общественный деятель Михаил Степанович Толмачев. Врачебные обязанности он совмещал с научной и статистической работой, которая выходила за рамки собственно медицины. В 1897 г. М. С. Толмачев издал обобщающее исследование о врачебной сети Московской губернии, снабженное планами зданий, таблицами и другим справочным материалом. Книга переиздавалась дважды. До сих пор это одна из лучших работ по истории земской медицины Московской губернии.

После Толмачева, в 1908-1941 гг. главным врачом больницы был Константин Александрович Боголюбов. Его именем названа одна из улиц города Истры.

В начале XX века лечебница по-прежнему оставалась лучшей в Московской губернии. Раздел о ней занимал почетное место на Международной гигиенической выставке 1911 г. в Дрездене: макет ее зданий находился в центре экспозиции Московской губернии. Прекрасная организация работы и 
подвижничество сотрудников наряду со многим другим определяли хорошую репутацию воскресенских медиков.

Воскресенская (Чикинская) больница была местом, где каждый год проходили практику выпускники медицинских факультетов и молодые врачи. Кроме блестящей профессиональной школы, Воскресенская больница давала еще и навыки работы в народе, этические основы земской деятельности.

Солидный клинический опыт, который получали молодые врачи в Воскресенской больнице, дал возможость многим из них сделать блестящую медицинскую карьеру. Но главным было воспитание в каждом из них особой земской этики, осмысленного и аскетического служения своему делу.

Знаменитый впоследствии земский деятель, прошедший школу П.А.Архангельского, знакомый Чехова, статистик медицины П.И. Куркин считал этический момент главным стимулом работы Чикинской больницы. «Что более всего затронуло меня, — писал он в пока еще неопубликованных воспоминаниях, - во всей этой неожиданно развернувшейся деревенской врачебной деятельности - это поистине душевное отношение к больному, которым проникнуты были все собравшиеся в стенах этого учреждения люди, делавшие изо дня в день свое скромное дело. Очевидно, дело это было нужное и необходимое, иначе, зачем бы массам страждущих больных, подчас жалких и убогих людей, с такими трудностями преодолевать расстояние, чаще всего в 5-10 верст и более, собираться здесь в амбулатории ежедневно такими огромными толпами, тратить силы и время на ожидание... Гуманный характер отношения к этой огромной массе населения, которая ежедневно течет сюда, поразил меня с огромною силою, захватил меня». [1]

А.П. Чехов, успешно сдав выпускные экзамены на медицинском факультете МГУ, летом 1884 года начал работу в Чикинской больнице. Он писал издателю Н. А. Лейкину в июне 1884 г., что через день ходит в земскую больницу, где ведет прием. Годом раньше он уже проходил здесь студенческую практику и привязался к постоянным и временным обитателям больничного городка. В 1885 г. Чеховы жили в Бабкине, но связи с Воскресенском не прерывались. Антон Павлович заменял в больнице доктора Архангельского, который взял короткий отпуск. Архангельский без колебаний доверил лечебницу своему молодому коллеге. Практически все 1880-е годы связаны у Чехова с этим подмосковным городком. [10] 
В 1883 - 1887 годах одновременно с Чеховым в больнице под руководством П. А. Архангельского работали многие будущие светила медицины, оставившие заметный след в науке, практической медицине, статистике.

Коллега Чехова по работе в Воскресенской больнице П.И. Куркин утверждал, что введенная П. А. Архангельским и его учениками строгая дисциплина, основанная на сознании общественного долга врача, была решающей в формировании нравственной силы, поражавшей современников в А.П. Чехове. Практика в Воскресенской больнице, общение с молодыми коллегами, тяжкий, но необходимый труд - все это составило едва ли не лучшее время в жизни А.П. Чехова.

"...Если бы я был около князя Андрея, то я бы его вылечил", - заметил Чехов по поводу смерти героя "Войны и мира". А в иронической полемике с Владимиром Гиляровским вопрошал: "Ты думаешь, я плохой доктор? Полицейская Москва меня признает за доктора, а не за писателя". [13]

Во "Всей Москве" напечатано: "Чехов Антон Павлович. Малая Дмитровка. Дом Пешкова. Практикующий врач".

Образ Чехова-врача намного бледнее образа Чехова-литератора, хотя его медицинская биография по драматизму и событийности никак не уступает биографии творческой. Отмечая в январе 1904 года 25 - летие литературной работы, Чехов мог бы за одно отметить и другую славную дату - 20 - летие выхода в жизнь в звании "уездного лекаря".

Об этом следует писать не только потому, что эта сторона жизни А.П. Чехова освещена недостаточно, но и потому еще, что некоторые биографы Чехова считают, что, став писателем, он практической медициной занимался между прочим, дилетантски, что работа врача тяготила его. Но это не так. Антон Павлович как-то писал Суворину: «...Я чувствую себя бодрее и довольнее собой, когда сознаю, что у меня два дела, а не одно. Медицина - моя законная жена, а литература - любовница. Когда надоест одна, я ночую у другой. Это хотя и беспорядочно, зато не так скучно, да и к тому же от моего вероломства обе решительно ничего не теряют...» [14]

1884 год - год окончания медицинского факультета Московского университета. Если внимательно вчитаться в строки его биографии, то обнаружится, что Чехов, как ни странно, прошел почти все ступени типичной карьеры русского врача. На студенческой практике был в сельской Чикинской больнице. Подменяя коллегу, заведовал Звенигородской больницей в Подмосковье. Из Звенигорода он писал, что волею судеб 
исправляет должность земского врача. [8] Полдня занят приемом больных (30-40 человек в день), остальное время отдыхает. Однако много отдыхать Чехову не приходилось, так как он не только принимал больных в земской больнице, но и исполнял должность уездного врача, исполнял поручения местной администрации, выступал экспертом на суде. Получил навыки судебно - медицинской работы - ему приходилось вскрывать тела погибших прямо на месте преступления - где-нибудь в поле, под зеленью молодого дуба...

В Москве занимался частной врачебной практикой - на дверях "домакомода" в Садово - Кудрине висела табличка: "Доктор А.П. Чеховъ". В годы наибольшего творческого подъема, в Мелихове, слыл за образцового земского врача. На холере возглавлял участок в 25 деревень, создав медпункты и ведя огромную лечебно-профилактическую работу, которая "съедала" все наличное время, а иногда доводила до отчаяния: "...Душа моя утомлена. Не принадлежать себе, думать только о поносах, вздрагивать по ночам и от собачьего лая и стука в ворота (не за мной ли приехали?), ездить на отвратительных лошадях по неведомым дорогам и читать только про холеру и ждать только холеры..." (8) Тем не менее, через пару месяцев чувство удовлетворения от полнокровной общественной и врачебной работы покрывало минуты малодушия: "Летом трудно жилось, но теперь мне кажется, что ни одно лето я не проводил так хорошо".

Трудно перечислить сферы медицины, где бы не остался чеховский след. Он сыграл ведущую роль в сохранении лучшего медицинского издания в России - журнала "Хирургия", на страницах которого увидело свет более полутора тысяч оригинальных статей. В Ялте вошел в число организаторов учреждений в помощь туберкулезным больным. И даже перед смертью мечтал поехать в Манчжурию военным врачом...

Не остался Чехов в стороне от медицинской науки. Еще в студенчестве задумал оригинальную работу об истории «полового авторитета». По окончании факультета начал кандидатскую диссертацию "Врачебное дело в России". Проштудировал объемистые летописные своды и сборники фольклорной мудрости, собирая по крупицам сведения о народном здравии во времена Владимира - Красное солнышко и Иоанна Грозного. По свидетельству однокашника Чехова, знаменитого профессора невропатолога Григория Ивановича Россолимо, Антону Павловичу не чужды были мысли о преподавательской деятельности.[8] Ученая степень, без 
которой невозможно получить кафедру, казалась ему "желательной". Чехову хотелось прочитать на медфаке курс, основанный на идеях его учителя профессора Г.А. Захарьина. Захарьин учил, что нет болезней "вообще" - есть конкретные больные, которых можно успешно вылечить при учете индивидуальных особенностей. Был однажды разговор и о том, как донести до студентов личностные переживания больного. Чехов размышлял так: "Я страдаю, например, катаром кишок и прекрасно понимаю, что испытывает такой больной, а это редко врачу бывает понятно. Если бы я был преподавателем. То я бы старался глубже вовлекать свою аудиторию в область субъективных ощущений пациента... Это студентам могло бы действительно пойти на пользу". Чеховская идея профессору Россолимо понравилась. В качестве докторской диссертации, по общему мнению, могла бы пригодиться книга "Остров Сахалин" - безупречное с точки зрения медицинской статистики описание условий жизни целого каторжного острова. Россолимо подошел с этой идеей к декану медфака профессору Клейну. Тот сделал большие глаза. Чехов посмеялся над неудачным "походом" в науку и целиком погрузился в литературу. [9] К тому времени Чехов был уже смертельно болен, и жить ему оставалось совсем недолго.

Мешала ли медицина Чехову - писателю? И мешала, и помогала. Мешала потому, что отнимала драгоценное время и силы от самого важного и главного в его жизни - писательства. Но медицина и помогала Чехову, ибо, по его собственному признанию, обогащала его научным пониманием психологии человека и интимных сторон его внутреннего мира. Сам Чехов на этот вопрос отвечал в письме к писателю Д.В. Григоровичу: «...Я врач и по уши втянулся в свою медицину, так что поговорка о двух зайцах никому другому не мешала так спать, как мне». [8]

И в воспоминаниях современников Чехова, и в его многочисленных письмах находится немало свидетельств тому, что на протяжении почти всей жизни он занимался практической медициной, которая былая для него ареной общественного служения народу. Не жалея средств и сил, он строил школы для крестьян, активно участвовал в борьбе с голодом и холерой, был инициатором строительства санаториев для туберкулезных больных, не имеющих средств на лечение. Но наиболее прямой и непосредственной формой помощи народу, служения ему была для него врачебная работа. Вот еще некоторые выдержки из писем Чехова. 
«...Когда я буду жить в провинции, о чем я мечтаю теперь день и ночь, то буду медициной заниматься и романы читать...»

«Душа моя изныла от сознания, что я работаю ради денег, и что деньги центр моей деятельности... я не уважаю того, что пишу, я вял и скучен самому себе, и рад, что у меня есть медицина, которою я, как бы то ни было, занимаюсь все-таки не для денег...» [8]

Чехов придавал большое значение распространению санитарных знаний среди широких масс населения; он ратовал за повышение квалификации врачей, мечтал об открытии Института усовершенствования врачей, принимал близко к сердцу судьбы медицинской прессы. Очень много сил и энергии пришлось приложить Антону Павловичу, чтобы спасти от гибели медицинские журналы «Хирургическая летопись» и «Хирургия». Признавая важность пропаганды медицинских знаний в народе и среди медицинских работников, Чехов призывал земских врачей активно участвовать не только в специальной медицинской, но и в общей печати.

Наша школа носит имя А. П. Чехова с 1944 года. Конечно, с именем Чехова связаны многие традиции школы. Это и прием в Чеховцы первоклассников, и Чеховская неделя в конце января, когда мы инсценируем рассказы писателя. Наша школа входит в маршрут Чеховской тропы города. В школе многие годы работает музей А.П. Чехова, который связан сотрудничеством со всеми музеями Чехова страны. Тем интереснее школьникам было изучить в своей проектной деятельности Чехова - врача, его вклад в становление земской медицины. У девятиклассников, через изучение истории Воскресенского земства, произошло понимание земской реформы, ее важности для истории страны. Тем более что и наша школа была построена в 1908 году именно Воскресенским земством.

Хочется закончить словами Д. С. Лихачева: «Любовь к своей Родине это не нечто отвлеченное. К патриотизму нельзя только призывать - его надо заботливо воспитывать. Воспитывать любовь к родным местам. Патриотизм начинается с малого - с любви к своей семье, своему дому, своей школе. Постоянно расширяясь, эта любовь к родному переходит к государству, его культуре, языку, истории, его прошлому и настоящему, а затем и ко всему человечеству. Не будет нравственных корней в родной местности, мы получим массу Иванов, не помнящих родства». 

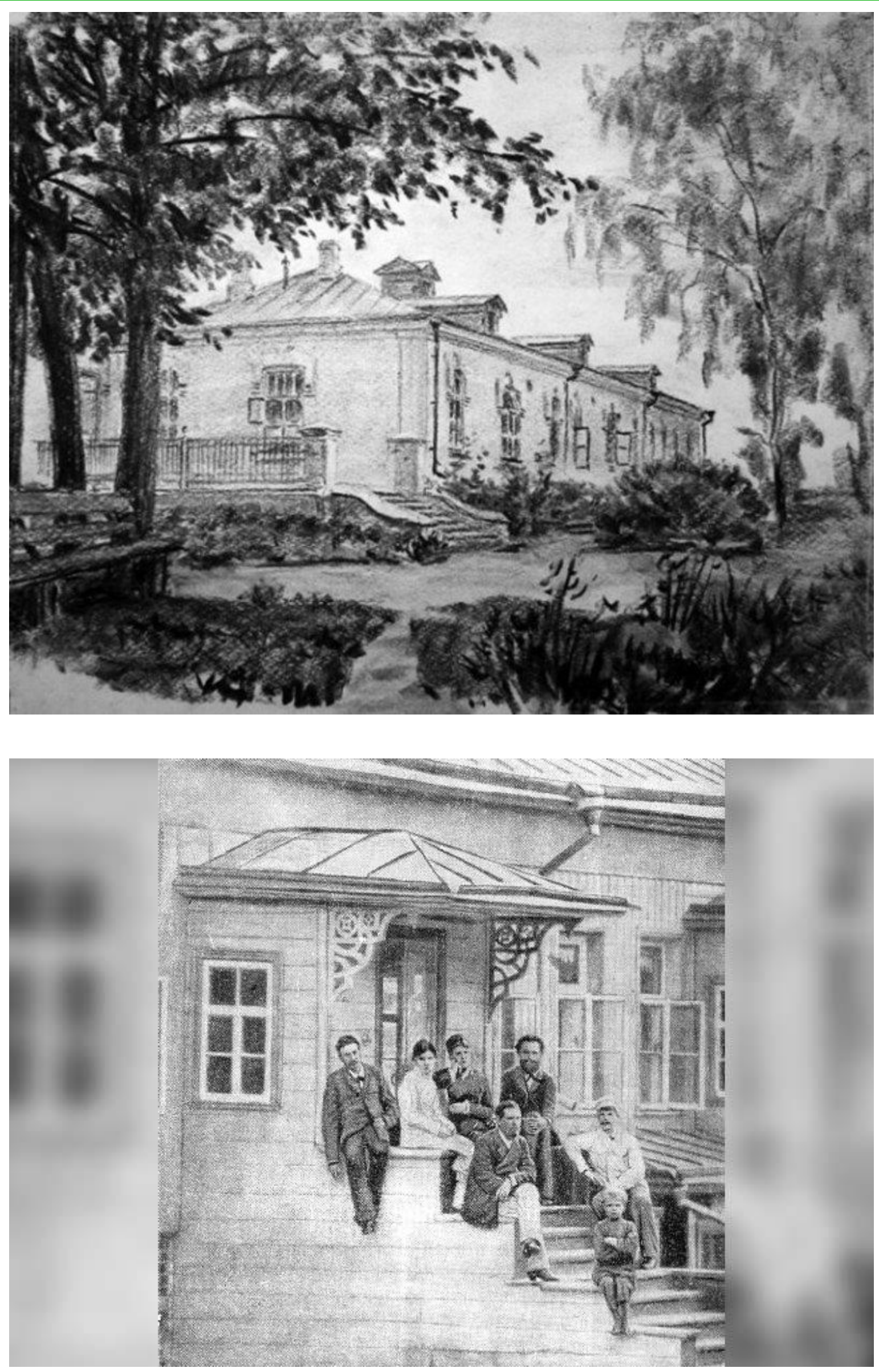


\section{Список литературы}

1. Земское самоуправление в России. Сборник в 2т. под ред. Н. Г. Королева. М., 2005.

2. Лаптева Л Е. Земские учреждения в России. М.,1993.

3. Лаптева Л.Е. Шутов А.Ю. Из истории земского и городского сословного самоуправления. М., 1999.

4. Сорокина Т. С. История медицины. 2-е издание, переработанное и дополненное. М.,1994.

5. Заблудовский П.Е. Медицина в России в период капитализма. Развитие гигиены. Вопросы общественной медицины. М., 1955.

6. Канцельбоген А.Г. Общественная и земская медицина в 60-80-е годы 19 века. М., 1988.

7. Левит М.М. Становление обществ. медицины в России, М., 1974.

8. У стен Нового Иерусалима. История города Воскресенска - Истры. Сборник под ред. Н. А. Абакумовой. М., 2010.

9. Истринская земля; Энциклопедия сел и деревень. М., 2004

10. Об Истре с любовью. Сборник в 3 т. М., 2006

11. Хижняков В.В. Антон Павлович Чехов как врач. М., 1947.

12. Чехова М.П. Из далекого прошлого. Чехов в воспоминаниях современников. М., 1952.

13. Гейзер М.И. Чехов и медицина. М., 1954.

14. Шалюгина Г.А. Чехов: жизнь, которой мы не знаем... Симферополь, 2004.

15. Чехов А. П. Полное собрание сочинений. Письма. М., 1972 